[楟化 第 35 巻, 第 14 号 p. 1412 1416, 1961]

稲熱病飞関する生化学的研究(第 20 報)*

いもち菌胞子の発芽機棈（その 2 )

いもち菌胞子中のピコリン酸について

小笠原長宏, 玉利勤治郎, 菅 正倫（新渴大学農学部農芸化学科）

昭 和 36 年 6 月 9 日受理

いもち菌胞子が稻葉上で発芽する場合，葉上の水滴中の胞子のみが発芽をし得るのであって，飽和湿度のみで は完全に発芽し得ないことは，多くの植物病理学者により強く指摘されて扣り，in vitroでも同様な結果が得ら れている(1〜8)。また洗淮胞子は未洗滌の胞子よりもその発芽が良好になることが認められた、かかることから， いもち菌胞子の発芽に水滴が必要である要因の一つとして, 我々は胞子内に発芽を抑制している物質が存在して 扣り発牙に際してその抑制物質が水滴中に放出されるのではないかと推察した．このような現象については，細 菌胞子がその発芽期にジビコリン酸を(゙)，まだる植物種子の発芽はその種子に含まれている発芽抑制物質を雨 により種子外に放出してから起る(5)等が見られている。前報(6)で明らかにしたようにいるち菌胞子の発芽はいむ ち菌自身の代謝産物であるピリクラリン（以下 Pir と略す）の 1 p.p.m. 及びピコリン酸（以下 PA と略す） の 400 p. p.m. でほぼ完全に抑制されるので，もしいもち菌胞子内K発来抑制物質が存在すれば，それはPir たはPA ではなから5かと考えて実験を行った結果, いるち菌胞子中には乾物量の約 $0.1 \%$ の PAが含有されて 特り，しかも胞子発芽に際してはPAが殆んど完全に水滴中に放出されることを確認した，胞子内のPAが発芽 飞際して胞子外一放出されることは, やはりPAが胞子の発芽機構と関連しているものであって，いもち菌胞子 の発芽に水滴の必要な要因の一つになっているものと考察される。な和 Pir はPAよりも微量代謝産物(7)である ので，胞子量が少いた奶確認できなかったとも考えられるので，さらに実験を行う予定である。

\title{
実験方法及び結果
}

実験に使用したいるら菌は農業技術研究所で分離され，その後当教室に保存してある $\mathrm{P}_{2}$ (费技研番号)を使用 した。

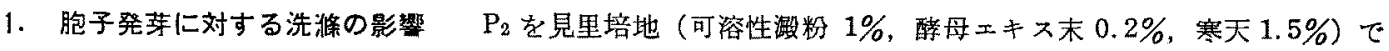
$28^{\circ}$ で 10 日間培盖して，その斜面から再蒸溜水を用いて胞子億濁液をつくる. これを 2,500 r.p.m， 2 分間の

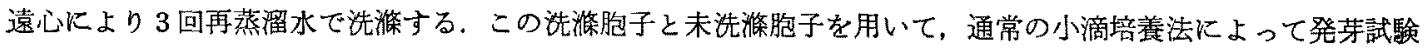
を行い，発芽率を $28^{\circ} ， 12$ 時間後に調べた， 1 例を第 1 表に示したが胞子濃度が高い場合に法洗策胞子の発芽率 は未洗溪胞子のそれより高いことが認められると共に他面胞子数が多いと先に得られている知見の如く発芽率が

第 1 表 胞子の洗淮と発芽との関係

$\left(28^{\circ}, 12\right.$ 時聞)

\begin{tabular}{|c|c|c|c|}
\hline \multicolumn{2}{|c|}{ 末洗涤胞子 } & 洗 淮 & 咆 \\
\hline 胞子濃度 & 発㧎率 $(\%)$ & 胞子濃度 & 発芽率 $(\%)$ \\
\hline $2 \times 10^{5} / \mathrm{ml}$ & 96 & $10 \times 10^{5} / \mathrm{ml}$ & 99 \\
\hline $38 \times 10^{5} / 1$ & 72 & $38 \times 10^{5} \|$ & 84 \\
\hline $60 \times 10^{5} / 1$ & 7 & $60 \times 10^{5} \|$ & 36 \\
\hline
\end{tabular}

要くなる傾向が見られるが，この場合でも洗淮した方 が一般に発芽率は良い，この結果と先汇述べた植物病 理学分野での知見とから胞子中にはその発芽を抑制し ている物質が存在しており，これが洗滌することによ り容易に水中に放出されるので洗策により胞子発芽が 良くなるのではないかと推察された。 このことは胞子 発芽の必須条件として水滴が必要であるとの事実を説

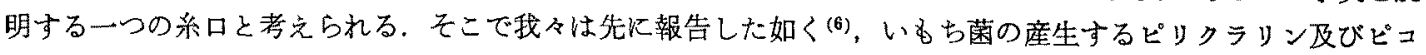

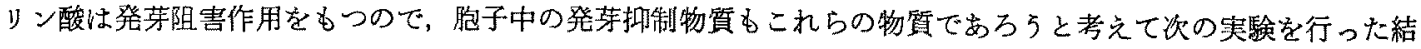
果, ピコリン酸が胞子中に存在することを確認した。

* Biochemical Studies on the Blast Desease of Rice Plant. Part XX. Mechanism on the Germination of Spores of Piricularia oryzae. (2) Presence in Spores of Picolinic Acid and the Changes Occurring During the Spore Germination.

By Nagahiro OGASAwARA, Kinjiro TAMARI and Masamichi SUGA (Department of Agricultural Chemistry, Faculty of Agriculture, Niigata University) 


\section{2. 分生胞子の大是採取の培䒧及び胞子採取法}

（1）培倠法： 前記見里培地を $600 \mathrm{ml}$ 容ルーフラスコに $150 \mathrm{ml}$ 分注し $110^{\circ}, 10$ 分正確に殺菌後寒天平板

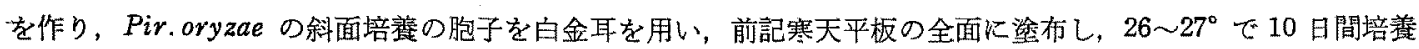

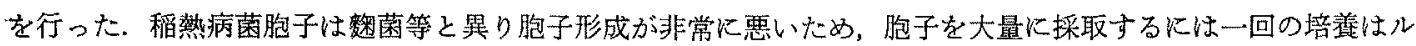
ーフラスコ 50 本を使用するが, 得られる胞子量は乾物量として $70 \mathrm{mg}$ 前後である.

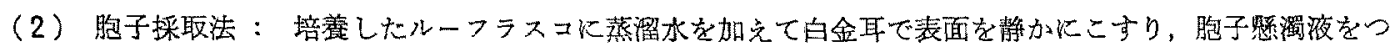
くり，まずガーゼ 4 枚で次にガーゼ 2 枚または薄い脱脂綿を用いて源過を行う。この操作により，笔濁液中に混 在する菌系は殆んと除去される。この滤液を $3,000 \mathrm{r} . \mathrm{p} . \mathrm{m}, 15$ 分遠心分雄して胞子を集める。この操作までに胞 子が 30 分以上墅濁液中に存在しない上5に充分注意をし，此をを得ないときは氷室に置くようにして操作を行 った. かくして得られた胞子を遠心分離により数回蒸溜水で洗湺して洗滌胞子を得る。

\section{3. ビコリン酸の分離及び確認}

（1）胞子から PA の抽出・分離法：柳田 ${ }^{(8)}$ は Aspergillus. niger の胞子のアミノ酸, 核酸等の分析の大

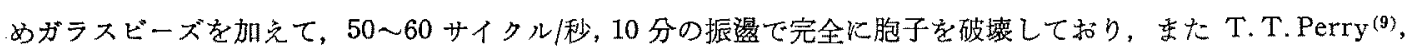
F.W.Janssen(10)は Bacillus 属の胞子の破㯖が $3 \mathrm{~N} \cdot \mathrm{H}_{2} \mathrm{SO}_{4}$ 中で 15 分劣沸亡たは $120^{\circ}, 15$ 分加熱で完全に行放 れることを報告している．いもも菌胞子は $2 \mathrm{~N} \cdot \mathrm{HCl}$ で $120^{\circ} ， 30$ 分加熱しても全く胞子は分解されないため，酸

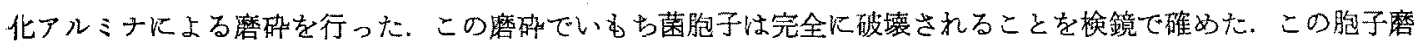
啸物から数回蒸溜水で抽出し，この抽出液を $\mathrm{pH} 3$ とし，96時間エーテル抽出を行った，前報(11)で報告した如く PA はこの条件で殆んど抽出される。エーテルを除去後真空デシケーター中で乾燥さ好る。この教燥試料を極く

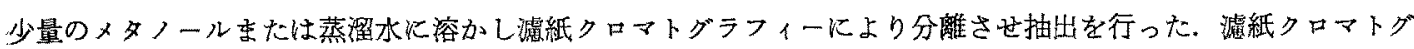
ラフィーはブタノール・酰酸・水 $(4: 1: 5)$ を展開剂として上型法により温度 20 2 $21^{\circ}$ で行った. 使用濾紙はメ

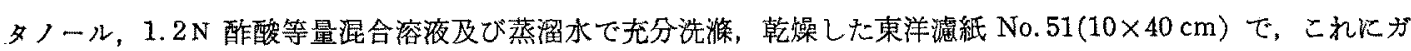

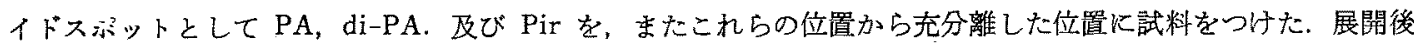
風乾しガイドスポットの濾紙片を切り取り，前二゙者は $0.2 \% \mathrm{BCP}$ (水飽和ブタノ一ル液)，後者はジアン゙試薬の噴

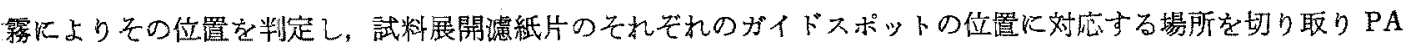
及びPir の部分はメタノール，di-PAの部分は熱水で抽出した，PA，di-PA 及びPirのRF值はそれぞれ0.42，

0.74 及び 0.82 であった.

\section{(2) PA の確認}

a）紫外部吸収スペクトルによる確認：再度裭紙クロマトグラ フィーにより分別してその渚紙クロマトグラムからの抽出溶液につ いて易津製分光光度計 QB-50 型に上り紫外部吸収スペクトルを求 めた. Blank 溶夜は試料をつけない濾紙同一溶媒で展開して, 各 ガイドスポットの位置に対応する濾紙片から前記と同一操作でそれ ぞれ抽出した溶液を用いた，その結果，PA 部分は $264 \mathrm{~m} \mu$ に極大 吸收を有する吸収スペクトルを示しこのスペクトルは標準 PA のそ れと全く一致する（第1図）ことが明らかになり胞子中にPA の存 在することが明らかになった。これに対し di-PA 及びPir の各部 分からはそれそれれ特有のスペクトルは得られなかった。

b) スポットテストによる確認(12)：PA 部分のメタノール抽出 液を真空デシケーター中で乾燥させると白色の粉末を極少量得る. これを $0.2 \mathrm{ml}$ の蒸溜水に溶かし，その一部をとり硫酸第一鉄の $1 \%$ 酢酸溶液に上る呈色反応を行了と淡黄色を示し，ほ注同一濃度 のPAの呈色と同一色調を示す。な标a）飞和斿る Blank 溶液を 洞一処理し，これについて同じ応を行っても呈色はしない。

c）滤紙クロマトグラフィーによるピコリン酸銅塩としての確 認(11)：上記実験に使用した陚料溶液の残りを全部東洋滤紙No. 51

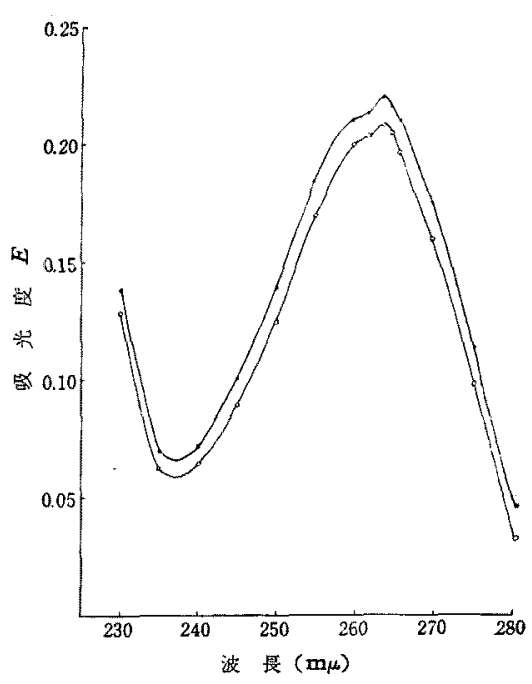

第1図いもち菌胞子から分雖したピコ リン酸の紫外部吸取スペクトルに よる磼認

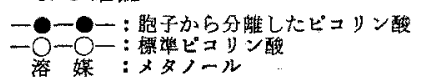


につけ，乾燥後そのスポットの上にさらに $0.5 \% \mathrm{CuSO}_{4}$ 溶液を $5 \mu 1$ つける. 対照としては標集 PAに

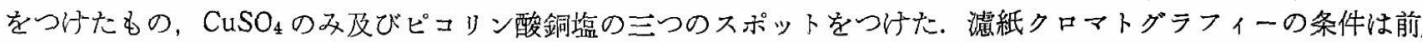
と同様で，影燥後銅の呈色試薬である $0.05 \%$ ルベアン酸のアセトン溶液を噴霧し更にアンモニアガスにさらす. その結果は写真 1 に示すよ 5 にピコリン酸銅塩は $R_{F} 0.64$ を示し，試

$\downarrow$ 铜一ピヌリン酸塔

料も同位置に灰緑色の呈色带を示すので試料はPA なることが確認され た.

4. 胞子中に含まれているPA の定量：上記の実験結果からいるち 3 菌胞子中にはPA が含有されていることが確認されたので胞子中の PA 4 の含有量を求めるべく实験を行った．胞子は前記と同様の方法で採取し 乾物量として, 67.2mg を得た。この胞子から同一操作で PA を抽出し て、ペーパークロマトグラフィーにより PA を分離し，PA を含む濾紙 片から $10 \mathrm{ml}$ のメタノールで溶出して, メタノールを除去, 乾燥後再度 濾紙クロマトグラフィーを行って分離し再び $5 \mathrm{ml}$ のメタノールで溶出

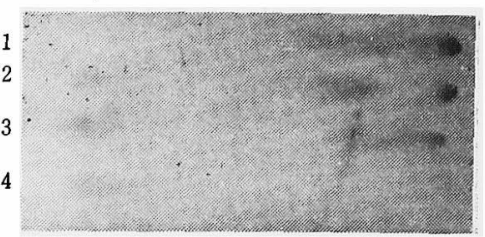

写真 1 銅ーピコリン酸塩として濾紙。 クロマトによる確認

1. $\mathrm{CuSO}_{4}$

2. サンプル $+\mathrm{CuSO}_{4}$

3. ピコリン酸 $+\mathrm{CuSO}_{4}$

4. 銅-ピコレート

する．このメタノール溶液について分光光度計によるPA の定量を行った。 このメタノール溶液の紫外部吸収ス. ペクトルは第 2 図の通りで，前実駼結果と同様標準ピコリン酸のそれと全く一致する．しかしてこのスペクトル． の $264 \mathrm{~m} \mu$ に猢ける極大吸収の吸光度は 0.294 を示し, これはPA の $9.6 \mu \mathrm{g} / \mathrm{ml}$ に相当するので試料全体の PA は $48 \mu \mathrm{g}$ となる.これが胞子 $67.2 \mathrm{mg}$ (乾物量) のPA 含有量であり, 含有率は約 $0.07 \%$ になる. 本法は. $80 \%$ 前後の回収率(1)のため実際量はこれより多い。

5. 胞子発芽時における PA の放出： いもち菌胞子は乾物量の $0.07 \%$ のA 含有していることが明らか. となったが，このPA が胞子中で如何なる役割を演じているか非常に興味のある点である. 即らいるち菌胞子の. 発芽が水滴中に损いてのみ可能であること法，PA が胞子発芽を抑制していて，水滴中と PA を胞子から放出す ることによりはじめて胞子は発芽し得る状態，即ち活性状態に执かれるものと推定して実験を行った結果，胞子 が発芽管の形成を行う前に含有するPA を全部放出することを確認した．前穾験法と同樣にして洗临胞子（乾物 量 $62.6 \mathrm{mg}$ ）を調製して，これに $50 \mathrm{ml}$ 蒸溜水を加克，この胞子を殺菌した $200 \mathrm{ml}$ 三角フラスコに入れ，270 3時間放置した. 3 時間後における胞子の発芽率は $8 \%$ を示し, 発芽管が微かに判別できる程度であった。 この，

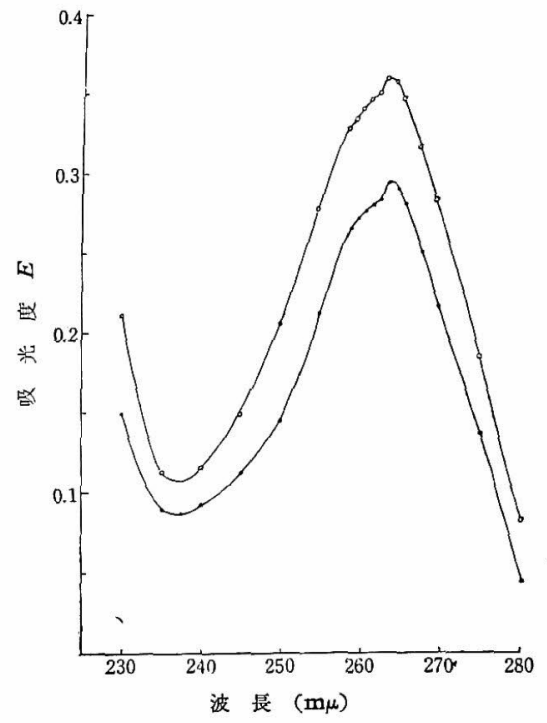

第 2 図胞子のピコリン酸含有量定量のた めの紫外部吸収スペクトル

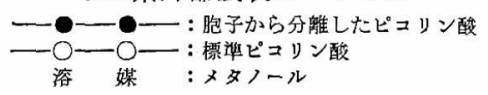

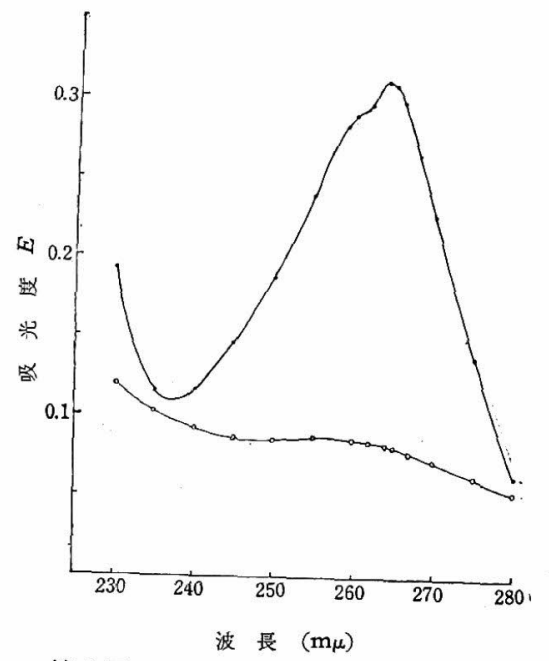

第3図いもち菌胞子からのピコリン. 酸の放出

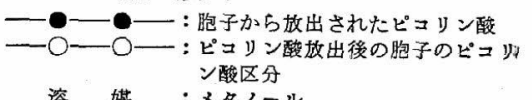

溶 媒 : メタノール 
馝濁液から遠心分離により上澄液をとり， $\mathrm{pH} 3.0$ として 96 時間連続エーテル抽出後エーテルを除去し，抽出 物を真空デシケーターで乾喿してPA 確認の試料とした，また遠心沈搌した胞子は前記胞子処理法と同一操作に 让り処理を行い，エーテル抽出して乾燥試料を得たＰＡ の確認法は前記方法と同一に行い，紫外部吸収曲線を

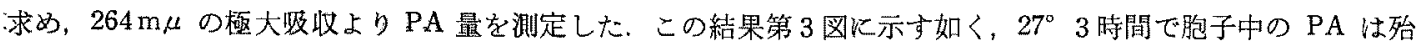

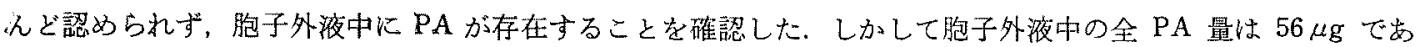
り，これは胞子含有量に換算ずる約 $0.09 \%$ に相当する。この事実は胞子中のPA が発芽管形成前に括いて殆 えと゚全て胞子外液中に胞子から故出されることを示すと共に, 前回の矢験と併世て胞子中にはPA が約 $0.1 \%$ 含 洧されていることが確認された。

\section{考察}

いもち菌胞子の発芽に際しては龙分量の水滴の存在することが必要であることは, 植物病理学分野で現象諭的 炕も確認されており，いもち発病に性稲葉上の露の存在が維対飞必要とされている. 我々はいるち菌胞子中に約

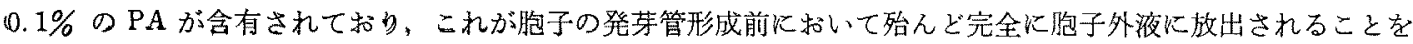

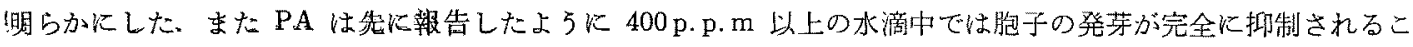

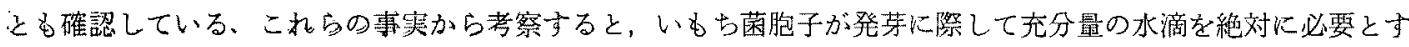
る要因の一つは胞子中のPA 放出するためであると考克る。な細菌胞子炕含有されている di-PA の存在は 喼められず，このことは柳田も，Asp．niger(19) の胞子に同酸の存在を認められないことを報告している．しか しいもち菌胞子飞おいてす胸子の発芽管形成前に胞子中のPA が外液に放出されるとい5ことは，細菌胞子に見 られる現象とよく似ているが，両者の胞子はその性質が全く異っているので，いもち菌胞子内の PA の役割が細

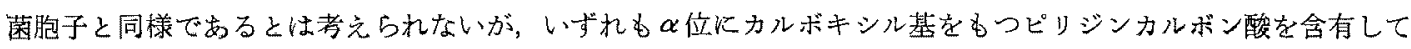
おり，共に発芽に際してそれを放出する点は極めて興味深いものがある。な特いもち菌胞子はその発芽に水滴を 絶対に必要々し，しかも蒸溜水中で完全な発芽を行い得るので，カビ胞子の中でも特別のグループに属するもの と考台られ，它の発芽形式は多くのカビの発芽型式とはいささか趣きを異にするものと推察される。またPAの 生成経路については最近粕尿病のテッテの尿中に多量のPAの生成することが確認されて，PAがトリプトフォ ンの分解生産物であり，ニシチン酸の前駆物質として知られている 3-OH アンスラニール酸から生成されること が A. H. Mehler (17,18)，O.Hayaishi(19,20)，に上り報告されている. しかし徽生物の代謝生産物として PA を生 成するものは，いもち菌以外洼報告(7)はなく，密た既火報告した如く，いもち菌はニコチン酸を生成する(21)の で，いもち菌胞子の発芽過程に拈けるPA の重要性と共にいもち菌代謝過程におけるPA 及びニコチン酸の生成 経路（動物の場合々同一であるか否か問題である）の追求は水稻の稲熱病生理と相俟って極めて興味樑いものが あり，目下追求中である。

要 約

いもち菌の胞子は約 $0.1 \%$ のピコリン酸を含有して扔り，它の胞子が登芽する際には胞子内のピコリン酸を主

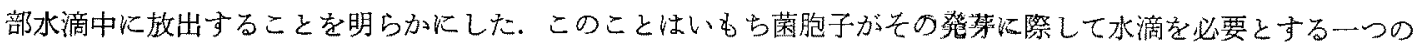
要因であると推察した.

釉りに臨み種々御助言を睗った新渴大学農学部平田幸治教授，東京大学農学部農芸化学天羽幹夫氏（現在アサ

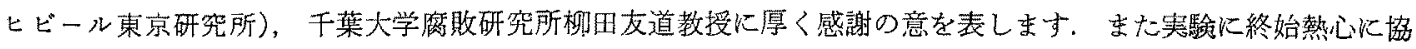
力された青木玄喜, 佐伯美外の諸兄にも深く謝意を表します。(な拈本実駼の 1 部は昭和 34 年 3 月 日農化大 会, 日植病大会で檴演した.)

(1) 安部卓爾: 植病研, 2,98(昭 8).

(2) 安部卓爾：日植病報，5，206(昭 10).

（3）逸見武雄: 病害誌, 25, 1 (昭 13).

(4) J.F. Powell, R.E. Strange : Biochem, J., 54, 205(1953).

（5）牧野岩男, 宮本隆夫：育種誌，4，158(1954),

（6）小笠原長宏, 玉利勤治郎, 菅正倫, 富樫邦渗; 本誌, 35, 1315 (1961).

（7）玉利勤次郎, 加治順：本誌，28，254(1954).
(8) T. Yanagita: Arch, Mikrobiol, 26, 329 (1957).

(9) J. J.Perry, J.W. Foster : J.Bact., 72, 295 (1956).

(10) H. H. Martin, J.W. Foster : ibid, 76, 167 (1958).

（11）小笠原長芸，玉利勤治郎，菅 正倫：本誌, 35, 1312 (1961).

(12) F. Feigl（野村祐太郎訳）：有機、ン点分析, 
共立出版，p. 285(昭 33))。

(13) 楖田友道: 日血化学会シンポシウム, 講演要 旨, p. 143(昭 33).

(14) G.R. Mandels : J. Bact., 65, 16(1953).

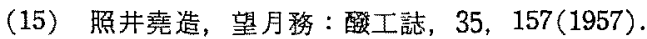

(16) 天羽幹夫：本誌，32，A 135 (1958).

(17) A.H. Mehler : J.Biol, Chem., 218, 241
(1956).

(18) A.H. Mehler : ibid., 223, 449 (1956).

(19) O. Hayaishi : Int.Synp. Enz. Chem. (Tokyo) p. 233(1957).

(20) 早石修: 蛋白質 核酸 醅菱, 3, 3(1958).

（21）大塚一止.玉利勤治郎，小笠原長䇪：本誌， $32,893(1958)$.

[農化 第 35 巻, 第 14 号, p. 1416 1424, 1961]

稲熱病に関する生化学的研究(第 21 報)*

いもち菌胞子の発芽機構 (その 3 )

いもち菌胞子内の発芽基質について

小笠原長宏, 玉利勤治郎, 菅 正偷, 富樫邦彦 (新潟大学農学部農芸化学科)

(昭 和 36 年 6 月 9 日 受理)

いもち菌胞子が蒸溜水中でのみ発芽することは植物病理学の分野に招いて確認されて括り，また洗淮胞子の方 が蒸溜水中で未洗滌胞子よりも発芽が良くなることも前報(1)に報告した．かようにいるち菌胞子はとの発芽に踏 して外的栄盖㳖存することなく，明らかに内的栄盖，即ら胞子内に盯蔵している基質に上って発芽を行5性質 を持っものであって，これは一般的に多くの系状菌胞子が外的栄養を必要とする発芽形式をとることとは異った 特殊の発芽といえる.而して外的栄養を必要とする胞子の発芽に関する必要因子については多くの研究がなされ ている(2 4)が，いるb菌胞子のよ5に内的栄養にのみ依存している胞子の発芽基質については報告が少いようで める.

我々は先に報告した胞子中のピコリン酸の実験に括いて，その試料中に相当量の有機酸が存在することを知っ たので，ます胞子内の有機酸を分析し，乳酸をはじめとして数種の有機酸を確認すると共に乳酸は他の有機酸沉 くらべてその量も多く，発芽と密接な関連のあることを見出した，さらに胞子は微量のグルコース，アラニンを はじぬ数種の遊離アミノ酸を含有していることも確諗して，これらの含有成分と発芽との関係についても知見を゙ 得たので報告する。

\section{実 験 及 び 結 果}

I. 胞子成分の抽出法 実験に用いる大量の胞子を採取する培責法は前報(1)と同様であって,ルーフラスコ を用いて見里培地に $28^{\circ} て ゙ 12$ 日閒培養したものである. 採取した胞子は良く蒸溜水で洗沙後酸化アルミナ（不

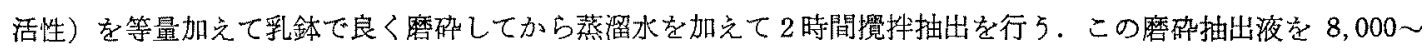

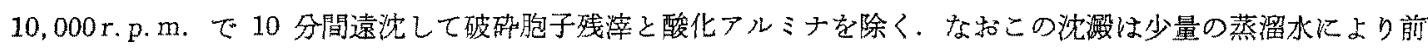
之同一条件の遠沈で洗策して洗涤液は最初の抽出液之合せて胞子抽出液を得る．この胞子抽出液から有機酸を分 離する場合には硫酸で $\mathrm{pH} 2.0$ とした胞子抽出液を $4 \sim 5$ 日間連続エーテル抽出を行って，得られるエーテル層 からエーテルを除去してエーテル可溶の有機酸区分を得る．これを真空デシターターで乾燥した後極少量の水を 加穴て加温乙蒸溜水可溶部分をとり，確諗実験の試料とする一方エーテル不溶の有機酸確認のためには胞子抽出

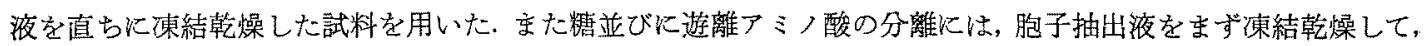

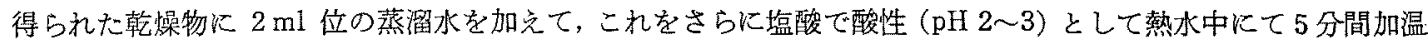
後冷却した液を 10,000 ～ 12,000 r. p. m. 10 分の遠沈を行って溶液の除蛋白を行った．この除蛋白液を中和後脱

* Biochemical Studies on the Blast Desease of Rice Plant. Part XXI. Mechanism on the Germination of Spores of Piricularia oryzae. (3) Relationships of the Spore Germination with the Substances Contained in the Spore.

By Nagahiro Ogasawara, Kinjiro Tamari, Masamichi Suga and Kunihiko Togashi (Department of Agricultural Chemistry, Faculty of Agriculture, Niigata University) 